\title{
РОЛЬ ГРОМАДСЬКИХ ОРГАНІЗАЦІЙ У СОЦІАЛЬНІЙ ІНКЛЮЗІї ДІТЕЙ 3 ІНВАЛІДНІСТЮ В УКРАЇНІ
}

\author{
Лещенко О. Г., кандидат педагогічних наук, доцент кафедри соиіальної педагогіки та \\ спеиіальної освіти, Запорізький наиіональний університет, м. Запоріжжя, Украӥна \\ DOI: https://doi.org/10.31435/rsglobal_conf/25012021/7355
}

\begin{abstract}
The article is devoted to the role of public organizations created by parents of children with disabilities in their inclusion in society. The author highlights the essence and principles of social inclusion, outlines international and national regulations that have become the basis for the development and implementation of inclusion in Ukrainian society. The article uncovers the concept of "disability", identifies challenges of families upbringing children with disabilities. Among the main problems faced by parents upbringing children with disabilities were defined as barriers to functioning, meeting the necessary needs of special children and creating discrimination in society. The author of the article reveals the essence of the concept of "public organizations" and gives examples of public organizations created by parents upbringing children with disabilities. The main directions of activity of these organizations were defined, which promote social inclusion of special children, regardless of the peculiarities of their psychophysical development, excluding any discrimination and ensuring equal attitude to all people.
\end{abstract}

Keywords: inclusion, social inclusion, disability, children with disabilities, participation in community life, public organizations.

Вступ. Сьогодні важливою умовою ефективної соціальної адаптації та інтеграції дітей 3 інвалідністю в суспільство $\epsilon$ інклюзивне навчання. Одним із пріоритетних напрямів політики української держави $є$ створення інклюзивного освітнього середовища для дітей з інвалідністю. Європейський досвід підтверджує те, що значна частина учнів з інвалідністю можуть навчатися за моделлю інклюзивної освіти, що передбачає надання якісних освітніх послуг школярам 3 особливими освітніми потребами у звичайних класах закладів загальної середньої освіти за умови відповідної підготовки вчителів та підтримки сімей, тим самим сприяючи включенню особливих дітей у суспільство.

Актуальність зазначеної проблеми зумовлена тенденцією до зростання кількості дітей, які потребують спеціальної освіти, що сприяла б їхній соціальній адаптації та включенню в активне суспільне життя. Як і в більшості країн світу, в Україні концепція інклюзивної освіти застосовується, як правило, до людей 3 особливими освітніми потребами. За даними Міністерства освіти і науки України на кінець 2020 року нараховувалось 18 тис. 687 інклюзивних класів, у яких навчається 30 тис. 971 дітей з особливими освітніми потребами.

Сьогодні питання соціальної інклюзії знаходить своє відображення у сфері освітньої політики, оскільки саме освіта $є$ віддзеркаленням стану суспільства й водночас важливим засобом його трансформації. Перехід до інклюзивної освіти є кроком на шляху до соціальної інклюзії та створення толерантного суспільства, як найбільш сучасної форми розвитку національної свідомості. Соціальна інклюзія є сучасною ознакою демократичного суспільства, яке гарантує кожному своєму громадянину рівні права та рівні можливості, незважаючи на особливості та багатоманітність.

Протягом останнього десятиліття питання інклюзії досліджували різні вчені. Так, В. Бондар, В. Засенко, А. Колупаєва, Т. Євтухова, В. Ляшенко, І. Іванова, О. Рассказова, Ю. Найда, О. Савченко, Н. Софій, А. Шевцов та інші присвятили свої праці питанням залучення дітей з інвалідністю до навчання у закладах загальної середньої освіти, розвитку соціальності учнів в умовах інклюзивної освіти; їхній реабілітації та соціалізації у суспільстві.

Проте включення дітей з інвалідністю у суспільство, їхня соціалізація стосується не лише сфери освіти, а й реалізації інших прав на дозвілля, спілкування, недискримінаційне ставлення оточуючих, доступ до ресурсів громади. У зв'язку з цим актуальним стає розуміння шляхів підтримки особливих дітей у процесі їхньої інклюзії.

Мета статті - визначити роль громадських організацій у реалізації соціальної інклюзії дітей з інвалідністю в Україні. 
Матеріали дослідження та отримані результати. Для досягнення мети нашого дослідження слід звернутись до визначення термінів «інклюзія» та «соціальна інклюзія». Сьогодні є декілька варіантів визначення цього терміну. В одному варіанті, інклюзія (від англ. inclusion - включення) розглядається у контексті включення й участі особистості у житті суспільства: як «процес посилення ступеню участі всіх громадян у соціумі, і насамперед тих, що мають проблеми у фізичному розвитку; цей процес передбачає розробку і застосування таких рішень, які створять умови для рівноправної участі кожної людини в академічному і суспільному житті» [10, 22]; «процес, спрямований на розвиток місцевих громад, які підтримують і високо цінують досягнення кожного члена громади» $[1,22]$.

В іншому варіанті, «інклюзія» розглядається у контексті освіти як «процес, спрямований на перетворення навчальних закладів на такий освітній простір, який стимулює й підтримує не тільки учнів, а і власних членів трудового колективу» [1, 22]. Це вказує на роль інклюзії у гуманізації суспільних відносин і дотриманні прав осіб з обмеженими можливостями на якісну та доступну освіту.

Проте для нашого дослідження важливо розкрити інклюзію стосовно включення дитини в суспільне життя. Для цього ми звернулись до поняття «соціальна інклюзія».

Поняття «соціальна інклюзія» визначено як «процес, спрямований на забезпечення людям, які зазнають ризику бідності та соціального вилучення, можливостей та ресурсів, необхідних для того, щоб повною мірою брати участь в економічному, соціальному та культурному житті та досягти рівня життя і добробуту відповідно до стандартів якості життя» $[4,12]$.

Розуміння сутності соціальної інклюзії розкривається через такі основні принципи концепції соціальної інклюзії:

- цінування, визнання і повага до окремих осіб з інвалідністю та всієї соціальної групи;

- розвиток людини, щодо надання можливостей для навчання, творчого інтелектуального зростання особистості;

- причетність та участь у процесі прийняття самостійних рішень особистістю 3 інвалідністю щодо сім’ї та життя у суспільстві (вибір послуг, що отримують; вибір батьками навчального закладу для дитини з інвалідністю; участь у прийнятті рішень щодо політики та участі у політичному житті суспільства);

- територіальна близькість передбачає доступ до спільного користування суспільним простором (громадські місця, бібліотеки, театри, транспорт тощо);

- матеріальний добробут - наявність матеріальних ресурсів, фінансової підтримки інклюзивних соціальних програм, проектів $[4,13]$.

Ці принципи акцентують увагу суспільства на сприянні у розвитку самостійності осіб 3 інвалідністю, розвитку вміння визначати власні ресурси та ресурси громади для вирішення проблем цієї категорії населення.

Питання соціальної інклюзії активно стало розвиватись у зв'язку із прийняттям таких міжнародних документів як Саламанська декларація, Конвенція ООН про права дитини та Конвенція ООН про права осіб з інвалідністю. Так, Саламанська декларація наголошує на сприянні участі батьків, громад та організацій осіб 3 інвалідністю щодо задоволення їхніх спеціальних освітніх потреб, а також на подоланні бар'єрів, дискримінації. У Конвенції ООН про права дитини зазначено перелік дитячих прав, дотримання яких сприятиме повноцінному розвитку дитини, включаючи дітей з інвалідністю; зазначено дії держави щодо реалізації цих прав. Відповідно до 24 статті Конвенції ООН про права осіб з інвалідністю наголошується «на праві осіб з інвалідністю на освіту...без дискримінації й на підставі рівності можливостей... та забезпечення інклюзивної освіти на всіх рівнях і навчання протягом усього життя» [3].

Упровадження Україною основоположних ідей цих міжнародних документів відображено у низці державних нормативно-правових актів: Конституція України, Закони України «Про освіту», «Про охорону дитинства», «Про реабілітацію інвалідів», «Про основи соціальної захищеності інвалідів в Україні» тощо. Саме у Законі України «Про охорону дитинства»[6] було змінено поняття «дитина-інвалід» на «дитина 3 інвалідністю» та «особа 3 інвалідністю 3 дитинства», що відображало зміну ставлення до такої дитини на більш толерантне та недискримінаційне.

Проте поняття «інвалідність» ще розглядають як бар’єр на шляху повноцінної участі в житті людей з порушеннями здоров’я. Такі бар'єри виникають у результаті взаємодії хвороби 
або хронічного захворювання із соціальним оточенням чи дискримінаційними діями, ставленням, культурою, політикою чи практикою, які проявляються у суспільстві по відношенню до цієї людини $[1,15]$. Ці бар'єри є порушенням прав людини з інвалідністю.

Аналіз нормативно-правової бази дозволив нам виділити такі основні права дітей 3 інвалідністю: на якісну освіту; на захист від дискримінації; на життя у сім'ї. Саме із соціальною інклюзією пов'язуються питання дотримання прав людини.

Вчені 3. Кияниця, І. Луценко визначили типові труднощі сімей, що виховують дітей 3 інвалідністю [9, 164-165]: фінансово-економічні; психологічні; медичні; недостатній розвиток і недоступність технологій ранньої діагностики, корекції, реабілітації, прогнозування медичних наслідків інвалідності; ризик інституалізації дитини з інвалідністю; проблема інформаційного забезпечення щодо особливостей дитини, можливостей корекції та іiї лікування, особливостей виховання, прав на соціальну допомогу, пільги, відповідних закладів освіти, наявних державних і недержавних громадських організацій.

Крім цих, зазначених вченими, проблем сімей, що виховують дітей з інвалідністю особливо слід наголосити на таких трьох: неприйняття людей з інвалідністю повноцінними членами суспільства, упередженість і стереотипність у ставленні до них з боку багатьох людей; недоступність певних об'єктів, споруд, проблеми транспортного забезпечення та доступу до інформації; недосконалість нормативно-правового забезпечення - виникнення суперечності між нормою закону і державно-управлінським забезпеченням виконання цих норм [9, 164-165].

Такий стан справ вказує на те, що незважаючи на імплементацію Україною гуманістичних засад, закріплених у Саламанській декларації про принципи, політику та практичну діяльність у сфері освіти осіб з особливими потребами, а також основоположних ідей Конвенції ООН про права осіб з інвалідністю, Конвенції ООН про права дитини, спостерігаємо порушення цих прав та ставлення соціуму до людини з інвалідністю як до такої, що не може самостійно функціонувати в суспільстві та $є$ залежною від допомоги інших.

Ці передумови сприяли розвитку соціальної активності батьків дітей з інвалідністю, які намагаючись забезпечити реалізацію прав власних дітей, почали створювати громадські організації.

Сьогодні Україна активно реалізує реформу децентралізації, за якою право вирішувати питання місцевого значення належать територіальним громадам. Основні положення створення та функціонування територіальних громад розкрито у Законі України «Про місцеве самоврядування в Україні». Дослідниця питання громади О. Безпалько визначила три підходи до iï розуміння: соціологічний (громада розглядається як спільнота чи соціальна система), соціально-педагогічний (громада розглядається як фактор соціалізації, мезорівень соціального середовища) та політико-правовий (громада розглядається як суб'єкт місцевого самоврядування). Для нашого дослідження найбільш актуальним є саме соціально-педагогічний підхід розуміння громади, оскільки громада виступає важливим фактором соціалізації особистості з інвалідністю.

На думку дослідниці Джуді Боп, громада характеризується як будь-яка група людей, які встановлюють сталі взаємини між собою з метою вдосконалення самих себе та світу, в якому вони живуть $[8,113]$. Саме батьки, що виховують дітей з інвалідністю у громаді виступають важливою рушійною силою для позитивних змін та включення власних дітей у суспільство.

Участь у житті громади - це активні дії членів громади, спрямовані на покращення функціонування громади, іiі розвиток, а також на особистісне самовираження та реалізацію власної громадянської позиції $[8,116]$. Активна життєва позиція батьків, що виховують дітей 3 інвалідністю, сприяє створенню та розвитку нових організацій, що контролюють виконання місцевих рішень, відстоюючи реалізацію прав власних дітей.

Важливим нормативно-правовим документом, що регулює діяльність громадських організацій є Закон України «Про громадські об’єднання». Цей документ визначає поняття «громадське об'єднання» як добровільне об'єднання фізичних осіб та/або юридичних осіб приватного права для здійснення та захисту прав і свобод, задоволення суспільних, зокрема економічних, соціальних, культурних, екологічних, та інших інтересів». Громадське об'єднання розрізняють за організаційно-правовою формою як громадську організацію або громадську спілку. Громадська організація - «це громадське об'єднання, засновниками та членами (учасниками) якого є фізичні особи» [5]. 
В Україні існує досить розгалужена система громадських організацій (далі ГО), що були створені батьками дітей з інвалідністю. Ці організації функціонують у різних містах країни. Наведемо деякі 3 них: ГО «Товариство реабілітації жінок з інвалідністю та жінок, які виховують дітей з інвалідністю «АСОЛЬ», ГО «Спілка батьків молоді з інвалідністю «Перспектива», ГО «Особливі діти», Кіровоградська обласна ГО матерів дітей-осіб 3 інвалідністю та осіб 3 інвалідністю «Серце матері», ГО дітей-осіб з інвалідністю та молоді з ДЦП «Наша родина», Благодійна організація «Одеська міська благодійна організація допомоги дітям 3 синдромом Дауна «Сонячні діти», ГО батьків дітей з інвалідністю «Богдан»; Волинська ГО батьків дітей із синдромом Дауна, Спілка батьків інвалідів із розладами аутичного спектру «Янголята», ГО батьків дітей із психофізичними вадами розвитку «Повір у себе»; ГО «АБ «ОСОБЛИВИЙ КІНДЕР», ГО «Товариство батьків дітей 3 інвалідністю та їх друзів «Зоря надії», ГО «Об’єднання батьків дітей хворих на цукровий діабет «Інсулін», Тернопільська міська ГО родин дітей-інвалідів «Дитина» та ін.

Громадські організації, що створені батьками 3 дітьми з інвалідністю провідним своїм завданням діяльності вважають інтеграцію та включення особливих дітей у суспільство. У своїй діяльності батьки дітей з інвалідністю грунтуються на таких цінностях інклюзії: «цінність людини не залежить від іiї здібностей та досягнень; кожна людина є здатною відчувати і думати; кожна людина має право на спілкування і на те, щоб ії почули; усі люди потребують підтримки і дружби ровесників; для усіх учнів прогрес скоріше може бути досягнутий в тому, що вони можуть, ніж у тому, що не можуть; освіта може здійснюватись краще в контексті реальних взаємостосунків» $[10,23]$.

Аналіз функціонування громадських організацій створених батьками, що виховують дітей з інвалідністю, дозволив нам виділити їхні основні напрями діяльності:

- сприяння розвитку та корекції порушень дітей з різними порушеннями;

- доступ до отримання корекційно-розвиткових послуг дітям 3 інвалідністю у віддалених районах, селах;

- фізична, психологічна, соціальна реабілітація;

- інклюзивно-змістовне дозвілля: відвідування театру, цирку, виставок, басейну, спортивних, творчих гуртків, мандрівки тощо;

- професійно-трудове навчання (наприклад, підготовка юного кулінара);

- налагодження соціального партнерства 3 різними фахівцями (корекційними педагогами, психологами, логопедами та ін.), державними та громадськими організаціями, благодійними фондами щодо реалізації прав особливих дітей на повне життя у суспільстві; потребами;

- соціальна адаптація та інтеграція у суспільство дітей 3 особливими освітніми

- інформаційна, психолого-педагогічна підтримка батьків, що виховують особливих дітей, посилення їхнього реабілітаційного потенціалу; підтримки.

- висвітлення інформації про свою діяльність серед членів громади та залучення їх до

Такі дії батьківських громадських організацій сприяють реалізації основних прав дітей 3 інвалідністю: права на освіту через доступ до інклюзивного навчання; права на недискримінаційне ставлення суспільства через доступ формування толерантності, гуманістичних цінностей, взаєморозуміння; права на сім’ю через збереження біологічної сім'ї, проведення спільного часу батьків зі своїми дітьми, а також через отримання підтримки всієї сім'ї щодо їхнього функціонування та активної участі у житті суспільстві.

Вчені 3. Кияниця, І. Луценко громаду, що здатна забезпечити сприятливі умови для розвитку потенціалу сімей, задоволення потреб дітей, утвердження гуманістичних цінностей, вважають громадою, дружньою до дитини. Виділяють три ознаки такої громади: 1) «у центрі уваги перебуває дитина, а їі благополуччя і безпека визнаються незаперечним пріоритетом; 2) упроваджується сімейно орієнтований підхід до надання соціальних послуг, встановлюються сталі дружні взаємини між людьми з метою вдосконалення самих себе та своєї спільноти (світу, в якому вони живуть); 3) система прийняття рішень грунтується на забезпеченні найкращих інтересів дитини» $[8,117]$.

Саме така громада орієнтована на реалізацію положень Конвенції ООН про права дитини [2] та гарантуватиме права дитини на безпеку; участь у житті суспільства й ухваленні 
рішень стосовно свого села, міста, громади; отримання оптимальних послуг з освіти, культури, охорони здоров'я; нормальні санітарні умови життя та доступ до чистої води; захист від жорстокого поводження; проживання на озелененій і чистій від забруднення території тощо.

Висновки. Узагальнюючи вищезазначене, слід сказати, що об'єднання батьків особливих дітей у громадські організації з метою їхнього розвитку та соціальної інклюзії має важливе значення. По-перше, це означає реалізацію права на освіту через залучення особливих дітей до навчання (причому батьки мають право обирати різні форми навчання: інклюзивне, спеціальне тощо). По-друге, такі громадські організації батьків сприяють отриманню дітьми з інвалідністю більших можливостей у розвитку та самореалізації у соціумі (корекційно-реабілітаційні заходи, дизайн середовища, доступ у громадські місця, дозвіллєві заклади тощо). По-третє, сім'я, здійснюючи підтримку особливої дитини, бере участь у прийнятті рішень у політиці держави щодо створення сприятливих умов включення дитини з інвалідністю у суспільство. По-четверте, відкритість та активна соціальна позиція батьківських громадських організацій з відстоювання прав дітей з інвалідністю сприяє формуванню у суспільстві гуманістичних цінностей, визнання і поваги щодо окремих осіб з інвалідністю та всієї соціальної групи.

\section{ЛІТЕРАТУРА}

1. Індекс інклюзії : загальноосвітній навчальний заклад : навчально-методичний посібник / кол. упорядників : Патрикеєва О. О., Софій Н. 3., Луценко І. В., Василашко І. П. Під заг. ред. Шинкаренко В. І., Київ : ТОВ «Видавничий дім «Плеяди», 2011. 96 с.

2. Конвенція ООН про права дитини, прийнята 20 листопада 1989 року. Retrieved from https://zakon.rada.gov.ua/laws/show/995_021\#Text

3. Конвенція ООН про права осіб 3 інвалідністю, прийнята 13.12.2006. Retrieved from https://zakon.rada.gov.ua/laws/show/995_g71\#Text

4. Найда, Ю. М., Ткаченко, Л .М. (2014). Стандарти громадсько-активної школи : соціальна інклюзія : навчально-методичний посібник / Під заг. ред. Даниленко Л.І. Київ : ТОВ «Видавничий дім «Плеяди», 2014. 68 c. Retrieved from http://elibrary.kubg.edu.ua/id/eprint/5617/1/y_naida_sgas_si.pdf

5. Про громадські об’єднання : закон України від 22 березня 2012 року № 4572-VI. Retrieved from https://zakon.rada.gov.ua/laws/show/4572-17\#text

6. Про охорону дитинства : закон України від 26 квітня 2001 року № 2402-III. Retrieved from https://zakon.rada.gov.ua/laws/show/2402-14

7. Саламанська декларація та рамки дій щодо освіти осіб з особливими освітніми потребами : прийнята Всесвітньою конференцією щодо освіти осіб з особливими освітніми потребами : доступ і якість. Саламанка, Іспанія, 7-10 червня 1994 p. Retrieved from https://zakon.rada.gov.ua/laws/show/995_001-94\#text

8. Соціальна робота з вразливими сім'ями та дітьми : посібник у 2-х ч.; Ч. І. Сучасні орієнтири та ключові технології / 3. П. Кияниця, Ж. В. Петрочко. Київ : ОБНОВА КОМПАНІ, 2017. 256 с.

9. Соціальна робота $з$ вразливими сім'ями та дітьми : посібник у 2-х ч.; Ч. ІІ. Соціальна робота 3 вразливими сім'ями та дітьми / за заг. ред.: Т. В. Журавель, 3. П. Кияниці. Київ : ОБНОВА КОМПАНІ, 2017. $352 \mathrm{c}$.

10. Теорія і практика інклюзивної освіти : навчально-методичний посібник / упор. Бондар К. М. 2-ге вид., доп. Проект «Підтримка інклюзивної освіти у м. Кривий ріг», 2019. 170 с. 